\title{
EXAMINING THE DRAFT CIPTA KERJA BILL IN THE PERSPECTIVE OF HUMAN RIGHTS TO ACHIEVE RESPONSIVE, ASPIRATIONAL AND PROGRESSIVE NATIONAL LAW DEVELOPMENT
}

\author{
Rama Halim Nur Azmi \\ Faculty of Law Brawijaya University \\ halimrama16@gmail.com
}

\begin{abstract}
President Joko Widodo in 2018 revealed the government's target of making law through the omnibus law to overcome the existence of regulatory obesity and overlapping regulations in Indonesia. One of the sectors the government has targeted for the enactment of the omnibus law is the employment sector. The drafting of the omnibus law bill on labor began in 2019 with the target completed within 100 days. At that time the draft law was called the Draft Cipta Lapangan Kerja Bill. However, in the draft last in February 2020 the draft law was named the Draft Cipta Kerja Bill. According to the Chairperson of the People's Legislative Assembly, Puan Maharani, hin the DraftCipta Kerja Bill, which was made in an omnibus law, consisted of 79 laws. The Draft of Cipta Kerja Billnotonly includes the employment sector but also other sectors such as the environment. However, the Cipta Kerja Bill has so far drawn rejection from the public, laborers, activists, academics, and practitioners because it is considered in the drafting of the Cipta Kerja Bill that it has problems both formally and materially, even according to some experts the Cipta Kerja Bill has the potential to violate human rights if authorized. In this paper, we will discuss the existence of the omnibus law as one of the mechanisms for the formation of laws and regulations and how the problems in the Draft Cipta Kerja Bill. The method used in this research is a normative juridical method with the statutory and comparative approach. The results of this study are an analysis of the existence of the omnibus law as one of the mechanisms for the formation of legislation and the existence of a picture and a critical attitude towards the issue of the Cipta Kerja Bill. So that through this paper, it can be seen whether the drafting of the Cipta Kerja Bill is intended for the interests of the people or only for the sake of investment which will certainly sacrifice human rights and harm national interests.
\end{abstract}

Keywords: omnibus law, Draft CiptaKerja Bill, employment, human rights.

Abstrak:Presiden Joko Widodo pada tahun 2018 mengungkapkan target pemerintah yakni membuat suatu undang-undang dengan cara omnibus law untuk mengatasi adanya obesitas regulasi dan tumpang tindihnya regulasi di Indonesia. Salah satu sektor yang menjadi target pemerintah untuk dibuatkan undang-undang omnibus law adalah sektor ketenagakerjaan. Penyusunan rancangan undang-undang omnibus law tentang ketenagakerjaan dimulai sejak tahun 2019 dengan target selesai dalam waktu 100 hari. Saat itu rancangan undang-undang tersebut dinamakan Rancangan Undang-Undang Cipta Lapangan Kerja. Namun, dalam draft terakhir pada Februari 2020 rancangan undang-undang tersebut bernama Rancangan Undang-Undang Cipta Kerja (RUU Cipta Kerja). Menurut Ketua Dewan Perwakilan Rakyat Puan Maharani dalam RUU Cipta Kerja yang dibuat secara omnibus law tersebut terdiri dari 79 undang-undang. Dalam RUU Cipta Kerja tersebut tidak hanya memuat tentang sektor ketenagakerjaan saja tetapi juga sektor-sektor lainnya seperti lingkungan hidup. Tetapi, RUU Cipta Kerja tersebut hingga saat ini menuai penolakan baik dari masyarakat, buruh, aktivis, akademisi, dan praktisi karena dinilai dalam penyusunan RUU Cipta Kerja tersebut memiliki masalah baik secara formil maupun materiil bahkan menurut sebagian ahli RUU Cipta Kerja berpotensi melanggar hak asasi manusia apabila disahkan. Dalam tulisan ini akan dibahas mengenai bagaimana keberadaan omnibus law sebagai salah satu mekanisme pembentukan peraturan perundang-undangan dan bagaimana permasalahan dalam RUU Cipta Kerja. Metode yang digunakan dalam penelitian ini adalah metode yuridis normatif dengan pendekatan peraturan perundang-undangan dan pendekatan perbandingan. Adapun hasil dari penelitian ini adalah adanya analisis terhadap keberadaan omnibus law sebagai salah satu mekanisme pembentukan peraturan perundangundangan dan adanya suatu gambaran dan sikap kritis terhadap permasalahan RUU Cipta Kerja. Sehingga melalui tulisan ini dapat terlihat apakah penyusunan RUU Cipta Kerja memang diperuntukkan kepentingan rakyat atau hanya demi kepentingan investasi semata yang tentunya akan mengorbankan hak asasi manusia dan merugikan kepentingan nasional.

Keywords:omnibus law, RUU Cipta Kerja, ketenagakerjaan, hak asasi manusia. 


\section{INTRODUCTION}

Indonesia is a state of law as expressly stated in Article 1 paragraph (3) of the 1945 Constitution of the Republic of Indonesia (hereinafter referred to as the 1945 Constitution of the Republic of Indonesia). Talking about the rule of law, of course, we cannot escape from the emergence of the concept of the rule of law since ancient Greek times. The conception of the rule of law stems from the fact that if a power is not restricted it will become an arbitrary and corrupt power. This is also expressed by Lord Acton in his adage which reads "Power tends to corrupt, absolute power corrupts absolutely". So, to limit the power the idea arises that power must be subject to the applicable laws of a country (supremacy of law).

In general, the conception of the rule of law in the world is divided into two namely the concept of rechtstaats and the rule of law. Friedrich Julius Stahl states the characteristics of rechtstaatsare: 1) Protection of human rights. 2)Separation or division of power for guarantee human rights are commonly known as TriasPolitica. 3) Government based rules. 4) Administrative justice in dispute. Also AV Dicey provides the characteristics of rule of law, namely: 1) Supremacy of law, in the sense that there can be no arbitrariness so someone can only be punished if breaking the law. 2) Equal position before the law, both for ordinary people and for official 3) Guaranteed human rights inlaw or court decision(Hamzani, 2014).

As a former Dutch colony, the conception of the rule of law adopted by Indonesia tends to lead to the concept of rechtstaats. However, Indonesia does not fully implement the concept of rechtstaats but also adheres to some of the principles of the rule of law to create its conception of the state law of Pancasila. In this conception the principle of rechtstaats and the rule of law is not positioned as two alternative or compulsive conceptions whose application can be chosen based on unilateral tastes, but rather as a cumulative conception as a mutually reinforcing unit. (Wijayanti et al., 2013).

As a rule of law one of the main things is the existence of laws and regulations as a product of the rule of law. If the law is a political product, the character of the legal product changes if the political configuration that gives birth to it changes. Throughout the history of the State of Indonesia, there have been political changes alternating between a democratic political configuration and an authoritarian political configuration. In line with these configuration changes, the character of legal products also changes. The thicker the legal content with the problem of power relations, the stronger the influence of political configuration on the law(MD, 2013)

Legal products in Indonesia as in Article 7 of Law Number 12 of 2011 concerning Formation of Regulations and Regulations as amended by Act Number 15 of 2019 concerning Amendments to Law Number 12 of 2011 concerning Formation of Regulations consisting of:

a.The 1945 Constitution of the Republic of Indonesia;

b. Decree of the People's Consultative Assembly;

c.Law/Government Regulation in Lieu of Laws;

d. Government regulations;

e.Presidential decree;

f.Provincial Regional Regulations; and

g. Regency/City Regulations.

Until now, the legal products of law in Indonesia in quantity reached thousands of laws. The Minister of Home Affairs for the 2014 - 2019 period Tjahjo Kumolo in the National Dialogue of the National Movement for Water Rescue on November 14, 2016, stated that Indonesia had more than43,000 laws and regulations, not including governor regulations or regent/major regulations(Simorangkir, 2016). President Joko Widodo in 2018 initiated an omnibus law concept to create efficiency and summarize thousands of laws to avoid disharmony and un-synchronized between laws and regulations.

Related to this it is necessary to understand in advance what is meant by the omnibus law. The definition of Omnibus Law starts from the word Omnibus. The word Omnibus comes from Latin and means it for everything. In the Black Law Dictionary, Ninth Edition Bryan A. Garner mentioned the omnibus: relating to or dealing with numerous objects or items at once; including many things or having various purposes, which means related to or dealing with various objects or items at once; 
including many things or having various goals. When coupled with the word Law, it can be defined as law for all(Rahardjo, 1981).

President Joko Widodo in his inaugural address conveyed the idea of streamlining regulations by forming two laws (Laws), namely the Employment Creation Act and the Act on Empowerment of Micro and Small and Medium Enterprises (MSMEs). The formation of these two laws will simultaneously cut dozens of regulations relating to MSME employment and empowerment. The formation of a single law comprehensively by consolidating several laws and regulations into the regulation of the new law is known as the omnibus law. According to the state constitutional law expert at LambungMangkurat University, MirzaSatriaBuana, the omnibus law can be considered a 'sweeping' law that can be used to replace several legal norms in several laws. This mechanism is considered more effective and efficient in the process of forming and revising laws(Rongiyati, 2019). Responding to the idea of establishing an omnibus law, the Ministry of Law and Human Rights and the Legislative Body (Baleg) of the House of Representatives of the Republic of Indonesia (DPR) have agreed to include the establishment of an omnibus law on employment and the empowerment of MSMEs in the 2020 National Legislation Program (Prolegnas) as a priority. As is known, the Government is trying to improve Indonesia's investment ranking, from ranking 73 in the world to rank 50 in 2021, one of which is through simplifying investment regulations. At least the omnibus law will cut 72 regulations that hamper investment(Rongiyati, 2019). The Draft Employment Copyright Omnibus Law is currently being changed to the Draft Employment Copyright Omnibus Law.

However, the Cipta Kerja omnibus law Bill currently being discussed in the House of Representatives is experiencing problems in both informal and material terms. The Center for Legal Studies at the Faculty of Law of the Islamic University of Indonesia states that the preparation of the draft omnibus law is a new method that has not been known in the formation of laws and regulations in Indonesia and the claims of efficiency that the government says cannot yet be proven. Philosophically, the drafting of the Omnibus law CiptaKerja is only for the sake of investment, not in the context of harmonizing laws and regulations in Indonesia(Utantoro, 2020).

Also, in substance, the substance in the CiptaKerja omnibus law Bill has many problems. For example, Article 166 which regulates regional regulations can be canceled by presidential regulation is a form of legal smuggling by reviving the provisions that have been declared unconstitutional by the Constitutional Court as stated in Decision of the Constitutional Court Number 56/PUU-XIV/2016. There are also many substances in the Draft Cipta Kerja Bill that violate human rights both in terms of employment and the environment(Putra, 2020).

\section{RESEARCH METHOD}

\section{A. Research Problems}

Based on the background that the writer described earlier, the formulation of the problem that can be drawn to determine the focal point in the next discussion is as follows:

1. What is the position of the omnibus law mechanism in the formation of laws and regulations?

2. What are the problems with the Draft Cipta Kerja (omnibus law) Bill?

\section{B. Research Methods}

This type of research in this article is normative juridical or also called doctrinal law research (B., no date), that is, researchers examine primary legal material (Soemitro, 1988)then proceed with research on secondary legal materials to answer the problems that are the focus of research that conceptualizes the law as a rule or norm which is a benchmark for human behavior that is deemed appropriate. The writing approach method used in this study is the statute approach, namely by analyzing and analyzing the statutory regulations(Widnjoesoebroto, 2002). A Comparative approach by examining how the application of the omnibus law mechanism in the formation of legislation in other countries.

\section{RESULT AND DISCUSSION}

\section{A. Omnibus Law Mechanism in the Formation of Legislation}

Omnibus law is a model for the formation of laws and regulations in which the substance changes and/or repeals several laws and regulations at the same time. The concept of the omnibus law 
was only known in Indonesia after President Joko Widodo conveyed it at the annual meeting in 2018. According to the Constitutional Law Expert FahriBachmid in the world of legal science, the concept of "omnibus law" is a concept of legal products that functions to consolidate various themes, materials, subjects, and legislation in each different sector to become one large legal product and holistic(Fitriyantica, 2019).

According to BivitriSavitri's Constitutional Law Expert, Omnibus Law is defined as a law (Law) created to target the major issues that exist in a country. Constitutional Law Experts ReflyHarun said that the application of the omnibus law could be done immediately because it was very good for establishing lean and harmonized rules. The problem is, it needs a special team to analyze what regulations need to be harmonized, partially or completely removed because relying on interministerial work can take a long time(Fitriyantica, 2019).

Omnibus law is also known by another term namely omnibus bill which has the following meanings (Gardner, 1999):

1. A single bill containing various distinct matters, usu. drafted in this way to force the executive either to accept all the unrelated minor provisions or to veto the major provisions. 2. A bill that deals with all proposals relating to a particular subject, such as an 'omnibus judgeship bill' covering all proposals for new judgeships or an 'omnibus crime bill' dealing with different subjects such as new crimes and grams to states for crime control.

A similar opinion was expressed by Briana Biersbach about the omnibus law and the omnibus bill (Suriadinata, 2019):

Just like a standard bill, omnibus bills are formal proposals to change laws that are voted on by rank and file lawmakers and sent off to the executive branch for final approval. The difference with omnibus bills is they contain numerous smaller bills, ostensibly on the same broad topic. Take the omnibus tax bill as an example: It may include changes in everything from income, corporate, and sales taxes, but all of those issues can fit under the large umbrella of taxes.

According to JimlyAsshiddiqie, there are three conditions for practicing omnibus law, namely the Act to be amended is directly related, the Act to be amended is not directly related, and the Act to be amended is not related but in practice intersects. At first, the concept of the omnibus law was conceived by SofyanDjalil who was then serving as Coordinating Minister for the Economy of the Republic of Indonesia. This saw the ease of doing business in Indonesia which was considered still difficult and convoluted(Suriadinata, 2019).

The concept of the omnibus law develops in countries that adhere to the common law system. This is because, in the civil law system, the concept of codification of laws and regulations is prioritized. Codification of laws and regulations is carried out to collect laws and regulations in one book. However, what is meant by the codification in the civil law system is certainly different from the intent of the omnibus law. In the concept of the common law system as conveyed by Henry Campbell Black the intended codification is "Process of collecting and arranging the laws of a country or state into a code, ie, into a complete system of positive law, scientifically ordered, and promulgated by legislative authority"(Prabowo, Triputra, and Junaidi, 2020).

The concept of the omnibus law has been applied in several countries such as the United States, Canada, Ireland, and Australia. In Ireland, one omnibus law was able to remove around 3,225 laws. Ireland's achievements are considered the world record for omnibus law practice. In the United States, the concept of the omnibus law is practiced in Transportation Equity Act regulations for the 21st Century (TEA-21) regarding federal highways, highway security, transit, and other transportation programs. In this TEA-21 about 9012 sections consisting of 9 chapters. While the practice of omnibus law in Australia can be seen from the Civil Law and Justice (Omnibus Amendments) Act 2015 which amended the Administrative Tribunal Appeal Act 1975, Bankruptcy Act 1966, Evidence Act 1995, Australian Federal Circuit Court 1999, Federal Court of Australia Act 1976 and International Arbitration Act 1974(Fitriyantica, 2019).

In addition, in 2002 Serbia also applied the concept of the omnibus law to regulate the autonomous status of Vojvodina Province. The law established with this concept covers the Vojvodina provincial government jurisdiction regarding culture, education, language, media, health, sanitation, health insurance, pensions, social protection, tourism, mining, agriculture, and sports. The omnibus law concept has also been adopted by countries such as Argentina, Austria, Belgium, Canada, Chile, Czech Republic, Denmark, Estonia, Finland, France, Germany, Greece, Hungary, Iceland, Ireland, 
Israel, Italy, Japan, Latvia, Liechtenstein, Lithuania, Luxembourg, Malta, The Netherlands, New Zealand, Norway, Poland, Portugal, Romania, Russia, Slovak Republic, Slovenia, Spain, Sweden, Switzerland, Taiwan, Thailand, and United Kingdom(Busroh, 2017).

For Indonesia, the concept of the omnibus law is a new thing so to form an omnibus law requires mature readiness. In Indonesia, the practice of omnibus law can be seen in Perpu Number 1 of 2017 concerning Access to Financial Information for Tax Interest in conjunction with Law Number 9 of 2017. Law Number 23 of 2014 concerning Regional Government. The Omnibus Law has been established at the TAP level of the Indonesian MPR, namely the Decree of the Republic of Indonesia Number I/MPR/2003 concerning Review of Material and Legal Status of the MPRS Decree and the Republic of Indonesia Decree of the 1960s to 2002(Fitriyantica, 2019).

The purpose of establishing the Omnibus Law is (Busroh, 2017):

a.Overcoming conflict of laws quickly, effectively, and efficiently;

b. Uniforming government policies both at the central and regional levels to support the investment climate;

c.Licensing management is more integrated, efficient, and effective;

d. Being able to break the long bureaucratic chain;

e.Increased coordination relationships between related agencies because it has been regulated in an integrated omnibus regulation policy;

$\mathrm{f}$. There is a guarantee of legal certainty and legal protection for policymakers.

When viewed in terms of the laws and regulations in Indonesia, the concept of the omnibus law has not been accommodated in Law Number 12 of 2011 concerning Formation of Laws and Regulations as amended by Law Number 15 of 2019 concerning Amendments to Law Number 122011 concerning the Formation of Legislation. Neither the academic manuscripts nor the omnibus law bill has not been found in the science of laws and regulations in Indonesia. So until now there is no official guidance on how the structure of the omnibus law if applied in Indonesia.

Besides, when viewed based on Article 10 of Law Number 12 of 2011 concerning Formation of Regulations and Regulations as amended by Law Number 15 of 2019 concerning Amendments to Law Number 12 of 2011 concerning Formation of Regulations which become the material contained in the law is:

a.further arrangements regarding the provisions of the 1945 Constitution of the Republic of Indonesia;

b. order of an Act to be regulated by law;

c.the ratification of certain international agreements;

d. a follow-up to the decision of the Constitutional Court; and/or

e.fulfillment of legal needs in society.

Based on these provisions there is no provision that in law the material contained in it may contain revocation and/or several laws and regulations starting from the center to the regional level at once. So before applying the concept of the omnibus law, it must first be regulated on how to model the formulation of the omnibus law, ranging from academic texts to draft laws.

Statistically as revealed by BappenasDuring 2000 to 2015, the central government issued 12,471 regulations, with the ministry becoming the largest producer with 8,311 regulations. The next type of regulation is 2,446 government regulations. Meanwhile, the regulations issued by the regional government were dominated by 25,575 regency/city regulations, followed by the provincial regulation with 3,177 regulations. Then, referring to the Indonesian Center for Law and Policy Study data, from 2014 to October 2018, 7621 Ministerial Regulations, 765 Presidential Regulations, 452 Government Regulations, and 107 Laws. The data does not include regulations issued in the span of the past year, from November 2018 to now(Badan Perencanaan Pembangunan Nasional, 2019). 


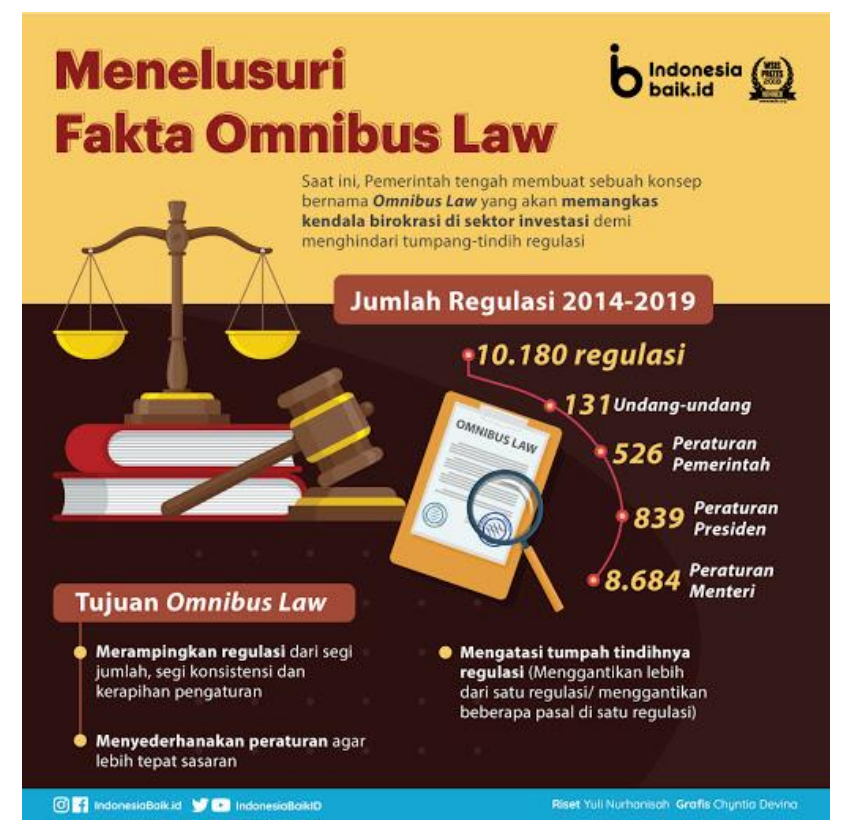

Figure 1. Infographic Obesity Regulations in Indonesia

References: (Nurhanisah and Devina, 2020)

So that when viewed statistically there is indeed obesity regulation in Indonesia. If the omnibus law mechanism is applied, it will certainly create efficiency in regulations in Indonesia and harmonization and synchronization of laws and regulations in Indonesia. The omnibus law mechanism certainly can overcome the overlapping problems of regulations and the many regulations that are issued in Indonesia.

However, the omnibus law mechanism is like a 'double-edged knife'. This is intended if the application of the omnibus law is imbued with political will from the government to streamline regulations in Indonesia so that the creation of justice and legal certainty will certainly have a positive impact on the life of the state. But if the application of the omnibus law is only imbued with enthusiasm to facilitate investment into Indonesia then this cannot be justified because it has indirectly sacrificed national interests by prioritizing investment interests alone. One concrete proof is the spirit of investment in the drafting of the Cipta Kerja's Omnibus Law, which until now has drawn polemics from various parties.

\section{B. Problems in Draft (Omnibus Law) Cipta Kerja Bill}

Design the Draft (Omnibus Law) Cipta Kerja Bill is one of the two agendas of the Government and the House of Representatives (DPR) to form an omnibus law. Previously, the CiptaKerja Bill was called the Draft CiptaLapangan Kerja Bill, but in the last draft of February 2020, the name of the CiptaKerja Bill was used. According to Puan Maharani, the CiptaKerja Bill consists of 79 laws with 15 chapters and 174 articles(Sari, 2020). The establishment of the Work Copyright Bill drew polemics from various parties due to problems both in formal and material terms. The problem, in this case, is considered to violate human rights.

From the formal point of view, the establishment of a Draft Cipta Kerja Bill starting from the drafting stage was not done transparently. This has been contrary to the concept of community participation in the process of forming the legislation. In Article 25 the International Covenant on Civil and Political Rights stated that The state is obliged to open public participation, guaranteeing the rights of each citizen to participate in making decisions on a rule, directly or through elected representatives(Hidayat, 2020). In the 1945 Constitution of the Republic of Indonesia in Article 28F it has also been stated explicitly that everyone has the right to obtain information. So that the actions of the Government and the Parliament that cover during the process of drafting the Draft CiptaKerja Bill are a form of violation of the right to information and formal violations namely the absence of public participation in the drafting of the Draft CiptaKerja Bill. 
Amnesty International Director Usman Hamid also said that the process of drafting the bill without disclosure to the public undermined the public's right to information. For him, eliminating community participation has a direct impact on workers, environmental activists, and the media. According to him, the drafting of the Draft CiptaKerja Bill only put forward the aspirations of state officials and entrepreneurs(Hidayat, 2020). Juridically in Article 96 of the Law Number 12 of 2011 concerning Formation of Laws and Regulations as amended by Law Number 15 of 2019 concerning Amendment to Law Number 12 of 2011 concerning Formation of Laws and Regulations concerning community participation, namely:

(1) The community has the right to give input verbally and/or in writing in the Formation of Legislation.

(2) Verbal and/or written input as referred to in paragraph (1) may be made through:
a. public hearing;
b. work visit;
c. socialization; and/or
d. seminars, workshops, and/or discussions.

(3) Community as referred to in paragraph (1) is an individual or group of people who have an interest in the substance of the Draft Legislation.

(4) To facilitate the public in providing verbal and/or written input as referred to in paragraph (1), each draft legislation must be easily accessible to the public.

The absence of public participation in the drafting of the Cipta Kerja Bill violates the provisions of Article 96 so it is only natural that the Cipta Kerja Bill starts refusals from various parties. In general, the benefits of community participation are:

a.Improve the quality of decisions/policies taken

b. Creating political awareness

c.Learning the process of democratization

d. Creating a responsible society

e.Increasing public trust in the Government

f. Means of communication between the public and the Government.

According to SatjiptoRahardjo, a law is said to be aspirational and participatory, if it can produce regulations that have the following characteristics (Riskiyono, 2015):

1. General and comprehensive, which is thus a kindness and special and limited traits;

2. Is universal, because laws are formed to deal with future events. Therefore, laws cannot be formulated to deal with certain events only; and

3. Has the power to correct and improve itself. Is it normal for a rule to include a clause that contains the possibility of a review?

There are 4 concepts of public participation (Riskiyono, 2015):

1. Participation as a policy. This concept views participation as a procedure for consulting policy-makers with the community as a subject of regulation;

2. Participation as a strategy. This concept sees participation as one of the strategies to gain public support for the credibility of the policies issued by the government;

3. Participation as a communication tool. This concept sees participation as a communication tool for the government (as a public servant) to know the desires; and

4. Participation as a dispute resolution tool. Participation as a tool for resolving disputes and tolerance for distrust and confusion in the community.

So that the absence of public participation in the establishment of the Cipta Kerja Bill is a form of denial of the process of democratization in the formation of legislation. Aside from being formal, the Draft CiptaKerja Bill also experienced problems in material terms. In this case, the author will provide an analysis in terms of human rights which is closely related to human rights and constitutional rights possessed by everyone.

According to the Center for Law and Human Rights Studies (Pusham) of Andalas University, there are several norm arrangements violate human rights in the substance of the Work Copyright Bill. This can be seen from the elimination of regulations concerning the responsibility of forest utilization permit holders for forest fires and the elimination of AMDAL permits in the industry so that they potentially violate the right to a healthy environment. Besides, the removal of wage arrangements in 
the Law and delegated to PP; work protection, work period scheme, and time off submitted to be regulated in PP; and discriminatory treatment between teachers/lecturers and teachers/lecturers who graduated from other state institutions of higher education related to certification(Redaksi WE Online, 2020).

The same thing was also conveyed by the Executive Director of the Indonesian Center for Environmental Law (ICEL) Raynaldo G. Sembiring that the CiptaKerja Bill endangered the environment. This can be seen from the removal of the provisions of Article 40 of Law Number 32 the Year 2009 concerning Environmental Protection and Management(Tim detikcom, 2020). The provisions of Article 40 are related to environmental permits as a condition for obtaining a business permit. An Environmental permit is one form of state administrative-legal instruments in the realm of environmental protection.

Permits are a preventive juridical government tool and are used as administrative instruments to control people's behavior. Therefore, the nature of a permit is preventive, because, in the permit instrument, it cannot be released with orders and obligations that must be obeyed by the permit holder(N.H.T., 2009). Also, the permit function is repressive. Permits can serve as an instrument for overcoming environmental problems caused by human activities inherent in the basis of licensing. That is, a business that obtains permission for environmental management is burdened with an obligation to deal with pollution or environmental damage arising from its business activities(Helmi, no date).

The regulation of environmental permits and their compliance is an effort towards sustainable development or in environmental economics is called "greening business management". Greening business management is an integrated environmental management strategy that includes the development of organizational structures, systems, and cultivation in a green competency by applying and obeying all regulations on environmental management, including management of raw materials, waste management, effective use of natural resources, use of production technology which produces minimal waste and implements environmental awareness commitments for all employees in the organization(Helmi, no date).

The existence of an environmental permit is a form of state efforts to protect the right to a good and healthy environment as one of the rights stipulated in the constitution as stipulated in Article $28 \mathrm{H}$ paragraph (1) of the 1945 Republic of Indonesia Constitution. Recognition and guarantee of protection of environmental rights that are good and healthy is a form of the concept of green constitution associated with the Ekocracy adopted in the amendment to the 1945 Constitution of the Republic of Indonesia or commonly known as the constitutionalizing of environmental norms in the Indonesian Constitution (Faiz, no date).

Recognition of the right to a good and healthy environment in our country cannot be separated from international influence as part of the State of the world. Internationally, environmental rights are contained in principle 1 of the Stockholm Declaration which reads(Kahpi, 2013):

The man has a fundamental right to freedom, equality, and adequate conditions of life, in an environment of a quality that permits a life of dignity and well-being, and he bears a solemn responsibility to protect and improve the environment for present and future generations.

The right to a good and healthy environment, as a subjective right as stated by HeinhardSteiger CS, is the most extensive form of protection for a person. So that in this case the right to a healthy and good environment, as a basic right of someone who must be protected to obtain an environment that can affect the survival of humans and other living things that are protected from pollution and damage to the environment in a healthy and good manner(Supriadi, 2005).

The emergence of Article 28H paragraph (1) of the 1945 Constitution of the Republic of Indonesia reflects the right to the environment, which doctrinally includes the absorption of the concept of the Third Generation of Human Rights into the amendment and emergence of Chapter XA on Human Rights, that the State recognizes, respects and upholds human rights humans over the environment (Yusa and Hermanto, 2018). The removal of the environmental permit requirement as a condition for obtaining a business permit is a form of denial of the constitutional mandate to protect the right to a healthy environment. That is because, in the absence of environmental permit conditions, entrepreneurs will easily get a business permit even if they do not have an environmental permit. Whereas environmental permit is a preventive instrument to prevent the occurrence of environmental damage which is detrimental to people's lives for the actions taken by a handful of entrepreneurs. 
In addition to human rights violations in the environmental sector, human rights violations also occur in the labor sector. According to the President of the Confederation of All-Indonesian Trade Unions (KSPSI) AndiGaniNenaWea explained why the workers were adamant in rejecting the Omnibus of Employment Copyright. The first is regarding the issue of wages. The wage problem will erase district and sectoral minimum wages. The UMSK (regency / municipal sectoral minimum wage) is divided into those that are manufactured, automated, and others that are deleted in the draft of the CiptaKerja Bill. Then, in the Omnibus Law Cipta Kerja Bill also does not regulate sanctions given to companies that do not give workers the rights. According to him, it would only make more and more companies do not give workers the right. Then, according to Andi, The Omnibus Law draft also allows companies to employ outsourcing and contract workers without time and type of work. The point, according to him, could harm all workers, not only the workers. The workers also highlighted the non-regulation of working hours in the Omnibus of Employment Law. Besides, laborers also refuse the permissibility of foreign workers (TKA) without restrictions in the field of work(Sugianto, 2020).

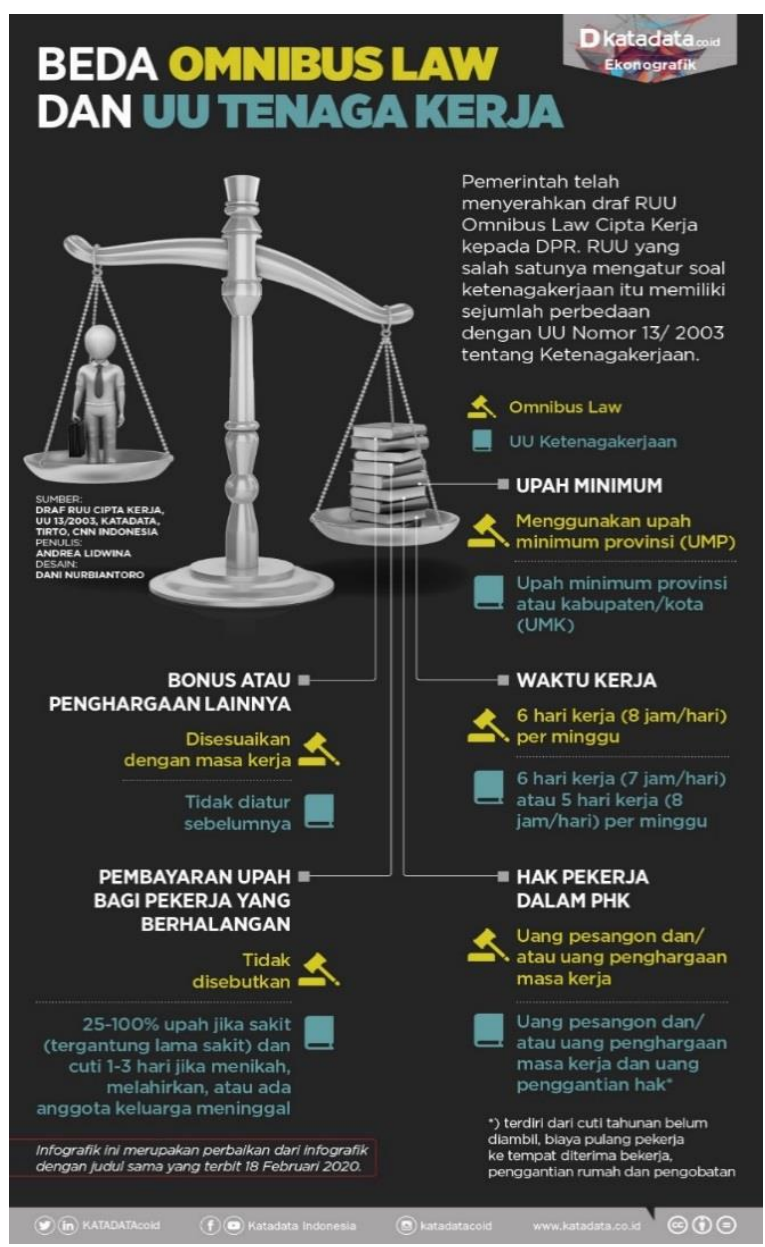

Figure 2. Infographics of the Differences between Draft Cipta Kerja Bill and Employment Bill References: (Lidwina, 2020)

The Cipta Kerja Bill is essentially focused on the employment sector. However, the CiptaKerja Bill that was made in an omnibus law appeared to be hasty and not transparent. So, there is no social control from the community over the substance in it. Therefore, the CiptaKerjaBill was rejected by various parties including laborers. The main focus that workers have always fought for is related to wages. Naturally, this has always been a starting point for workers' struggles because through decent wages workers can have a decent living. This is inseparable from human rights, especially the right to get a job and get a decent salary.

The right to work has been outlined in Article 23 paragraphs 1 to 4 of the Universal Declaration of Human Rights (UDHR) which reads as follows (Mustari, 2016): 
1. Everyone has the right to work, to free choice of employment, to just and favorable conditions of work, and to protection against unemployment.

2. Everyone, without any discrimination, has the right to equal pay for equal work.

3. Everyone who works has the right to just and favorable remuneration ensures for himself and his family an existence worthy of human dignity, and supplemented, if necessary, an existence worthy of human dignity, and supplemented, if necessary, by other means of social protection.

4. Everyone has the right to form and to join trade unions for the protection of his interests.

Based on the division of human rights groups, the legal protection of the rights of women workers is closely related to human rights in the economic, social, and cultural fields, namely rights related to work. Furthermore, the grouping of rights related to work is divided into four groups namely(Mustari, 2016):

a. Work-related rights

b.Rights derived from work

c. Rights relating to fair and non-discriminatory treatment

d.Instrumental rights.

The second group of rights includes rights and freedoms derived from the rights and freedoms at work as a result of the existence of an employment relationship between the employer and the recipient of work. Rights in the second group include the right to fair working conditions (such as working hours, annual leave payments, and rest periods) the right to healthy and comfortable working conditions, the right to fair wages, and the right to training and work guidance, as well as the right the rights of women and young people for protection at work and the right to social security and others(Mustari, 2016).

The third group of rights sees rights at work from the perspective of fair and nondiscriminatory treatment. This approach has a basis for all international agreements on social rights as well as in special agreements relating to non-discriminatory issues. The fourth group is the instrumental rights are the rights that provide or provide a basis that cannot be ignored for the implementation that forms a favorable framework so that without it, implementation relating to work cannot be done without obstacles or seriously impeded. These instruments are the right to freedom of association, the right to negotiate, the right to collective bargaining, the right to strike, and the right to migrate workers, the right to own property, freedom, and the security of people(Mustari, 2016).

Protection of labor is a necessity that must be considered by the government, especially in democratic rule of law. This is because every worker has rights that must be protected by the government. Protection of workers' rights must be done because there is an imbalance between the position of the worker as the recipient of the work and the employer as the employer. So that the government in this case acts as a third party in the relationship between workers and employers.

Workers' rights are the right to obtain decent work for humanity that has been recognized in the 1945 Constitution which is a constitutional right. So that the state is not allowed to issue policies either in the form of laws (legislative policy) or in the form of implementing regulations underneath (bureaucracy policy) reducing the substance of constitutional rights. Even in the concept of the welfare state the state is obliged to guarantee the implementation of constitutional rights. Likewise, nonhuman rights undergo a process under the interests and development of the community regulated inlaws and regulations. In connection with the existence of state obligations in exercising constitutional rights(Mustari, 2016):

a.The intervention of the government on aspects of community life is very broad.

b. In the implementation of government functions often used the principle of discretion.

As a manifestation of the constitutional mandate to provide protection related to the rights possessed by government workers has issued Law No. 13 of 2003 concerning Labor. The Manpower Law is currently being planned to be amended through the Employment Copyright Bill that was made in an omnibus law. However, the paradigm used by the government in the drafting of the CiptaKerja Bill is to accelerate investment, which of course has the potential to violate human rights. This happens because there is a conflict of interest in which the employer uses the economic principle of spending a little capital and getting the maximum profit. While workers are principled to get a large wage. 
Article 28 I paragraph (4) of the 1945 Constitution of the Republic of Indonesia explicitly states that the protection, promotion, enforcement, and fulfillment of human rights are the responsibility of the state, especially the government. Likewise, it is explained in Law Number 39 of 1999 concerning Human Rights Article 71 which states(Jailani, 2011):

The government is obliged and responsible to respect, protect, uphold and advance the human rights stipulated in this law, other legislation, and international law concerning human rights that are accepted by the Republic of Indonesia.

Based on the order of the law it is clear that the government has the responsibility to respect, protect, uphold and advance human rights. Universally, the state bears the primary responsibility for the promotion and protection of human rights. Such responsibilities cannot be reduced by political, economic, or cultural reasons(Bahagijo and Nababan, 1999). So that the reasons for accelerating investment cannot be justified because even though it aims to improve the economy, human rights must still be considered without exception.

The draft The Work Creation Bill as conveyed by ZainalArifinMochtar expressly positions that human rights are an obstacle to investment and therefore must be ignored (Mochtar, 2020). This shows that the paradigm used by the government in drafting the Work Creation Bill is solely based on investment interests without considering whether it contradicts and harms human rights. So that when viewed from the perspective of human rights the Draft CiptaKerja Bill if it is passed by the government together with the Parliament will create a legal product that is contrary to human rights.

The drafting of the CiptaKerja Bill also does not at all show the characteristics of progressive law during the midst of the current development of national law. The concept of progressive law proposed by SatjiptoRahardjo when interpreted simply means "how" to allow the law to flow to complete its task of serving humanity and humanity. The main points of this progressive legal model can be described as follows(Sasmita, 2012):

1.The law rejects the analytical tradition of jurisprudence or rechtsdogmatiek and shares understanding with streams such as legal realism, freirechtslehre, sociological jurisprudence, interressen jurisprudenz in Germany, natural law theory, and critical legal studies.

2.The law rejects the opinion, that order (order), only works through state institutions.

3.Progressive law is aimed at protecting people towards the ideal of law.

4.The law rejects the status-quo and does not want to make the law a technology without conscience, but rather a moral institution.

5.Law is an institution that aims to bring people to a just, prosperous life and make people happy.

6.Progressive law is "law that is pro-people" and "law that is pro-justice".

7.The basic assumption of progressive law is that "law is for humans", not vice versa. Related to this, the law does not exist for itself, but something broader and bigger. So every time there is a problem in and with the law, the law is reviewed and corrected, not humans are forced to be included in the legal system.

8.The law is not an absolute and final institution but rather depends on how humans see and use it. It is a man who is the determinant.

9.Law is always in the process of continuing to be (law as a process, a law in the making).

The CiptaKerja Bill does not at all show the characteristics of progressive law. This can be seen from the Work Cipta Bill that shows laws that are not pro-people but pro-investors. So that the Draft CiptaKerja Bill as long as there is no political will from the government and the Parliament to improve the Draft DraftCiptaKerja Bill, the Draft DraftCiptaKerja Bill must be rejected because formally and materially the Draft Work Draft violates human rights principles and directly contradicts the constitution.

\section{CONCLUSIONS}

As a legal state, the existence of law as a legal product is a necessity as a mechanism to regulate the life of the nation and state. In establishing a law, a certain mechanism is certainly needed. In Indonesia, the mechanism for the formation of these laws and regulations is regulated in Law Number 12 of 2011 concerning Formation of Laws and Regulations as amended by Law Number 15 
of 2019 concerning Amendments to Law Number 12 of 2011 concerning Formation of Laws and Regulations Invitation. However, in the context of national development, an omnibus law mechanism emerged, which has only been known in the common law system.

The establishment of the CiptaKerja Bill currently reaps opposition from various parties due to several problems in the drafting process. Problems in the CiptaKerja Bill occur both formally and materially. Formally the problem of the CiptaKerja Bill is the lack of community participation in the process of drafting the CiptaKerja Bill so that it does not reflect aspirational drafting of the law. Materially, the CiptaKerja Bill also has substantial problems. The substance of the Cipta Kerja Bill is considered to violate the principles of human rights, especially relating to the environment and labor. From the environment sector, if the government removes crucial articles that are closely related to environmental protection, it shows the existence of a government obligation to protect the environment. From the labor sector, if the government continues to insist on the investment paradigm at the expense of workers' rights, the government has essentially discriminated against by benefiting only one party.

Therefore, in responding to the drafting of the Omnibus law, the Cipta Kerja Bill must be critically examined by looking at it from many perspectives, one of them from the perspective of human rights. This is sole because in the conception of the rule of law one of its main features is the protection of human rights. If the government does not protect human rights, it can be said that there are arbitrary actions taken by the government towards its people. Besides, a critical attitude towards the Cipta Kerja Bill is also a form of community aspirations in the formation of legislation leading to the development of responsive, progressive, and aspirational national laws.

\section{REFERENCES}

B., S. (no date) Karakter Penelitian Hukum Normatif dan Sosiologis. Yogyakarta: Puskumbangsi LEPPA UGM.

Badan Perencanaan Pembangunan Nasional (2019) Kajian Reformasi Regulasi di Indonesia: Pokok Permasalahan dan Strategi Penanganannya. Jakarta.

Bahagijo, S. and Nababan, A. (1999) Hak Asasi Manusi: Tanggung Jawab Negara Peran Institusi Nasional dan Masyarakat. Jakarta: Komnas HAM.

Busroh, F. F. (2017) 'Konseptualisasi Omnibus Law dalam Menyelesaikan Permasalahan Regulasi Pertanahan', Arena Hukum, 10(2), p. 241.

Faiz, P. M. (no date) 'Perlindungan terhadap Lingkungan dalam Perspektif Konstitusi', Jurnal Konstitusi, 13(4), p. 770.

Fitriyantica, A. (2019) 'Harmonisasi Peraturan Perundang-Undangan Indonesia melalui Konsep Omnibus Law', Jurnal Gema Keadilan, 6(III), p. 303.

Gardner, B. A. (1999) Black Law Dictionary. 7th eds. St. Paul MN: West Publishing Co.

Hamzani, A. I. (2014) 'MENGGAGAS INDONESIA SEBAGAI NEGARA HUKUM YANG MEMBAHAGIAKAN RAKYATNYA', Yustisia, 90, p. 137.

Helmi (no date) 'KEDUDUKAN IZIN LINGKUNGAN DALAM SISTEM PERIZINAN DI INDONESIA', JURNAL ILMU HUKUM, 2(2), p. 3.

Hidayat, R. (2020) RUU Cipta Kerja Tiga Sektor Ini Potensial Langgar HAM, Hukumonline.com. Available at: https://www.hukumonline.com/berita/baca/lt5e60c7d14ae17/ruu-cipta-kerja-tigasektor-ini-potensial-langgar-ham/.

Jailani, M. (2011) 'TANGGUNG JAWAB NEGARA DALAM MEMBERIKAN PERLINDUNGAN TERHADAP HAK-HAK KORBAN PELANGGARAN HAM BERAT DI INDONESIA', Syiar Hukum, XIII(1), pp. 83-97.

Kahpi, A. (2013) 'Jaminan Konstitusional Terhadap Hak atas Lingkungan Hidup di Indonesia', AlDaulah, 2(2), pp. 143-159. Available at: http://journal.uinalauddin.ac.id/index.php/al_daulah/article/viewFile/1472/1420.

Lidwina, A. (2020) Beda Omnibus Law dan UU Tenaga Kerja, Katadata.co.id. Available at: https://katadata.co.id/infografik/2020/02/18/beda-omnibus-law-dan-uu-tenaga-kerja (Accessed: 29 May 2020).

MD, M. M. (2013) Politik Hukum di Indonesia.

Mochtar, Z. A. (2020) 'Politik Hukum RUU Cipta Kerja', Harian Kompas, March, p. 6. 
Mustari (2016) 'HAK ATAS PEKERJAAN DENGAN UPAH YANG SEIMBANG', Jurnal Supremasi, XI, pp. 108-117.

N.H.T., S. (2009) Hukum Lingkungan. Jakarta: Pancuran Alam.

Nurhanisah, Y. and Devina, C. (2020) Menelusuri Fakta Omnibus Law, indonesiabaik.id. Available at: http://indonesiabaik.id/infografis/menelusuri-fakta-omnibus-law (Accessed: 23 May 2020).

Prabowo, A. S., Triputra, A. N. and Junaidi, Y. (2020) 'Politik Hukum Omnibus Law di Indonesia', Jurnal Pamator, 13(1), p. 4.

Putra, A. (2020) Masalah Hukum Undang-Undang Cipta Kerja, Tempo.co. Available at: https://kolom.tempo.co/read/1308386/masalah-hukum-undang-undang-cipta-kerja.

Rahardjo, S. (1981) Hukum, Masyarakat \& Pembangunan. Bandung: Alumni.

Redaksi WE Online (2020) Poin-Poin Bermasalah dalam RUU Cipta Kerja, Warta Ekonomi. Available at: https://www.wartaekonomi.co.id/read273934/poin-poin-bermasalah-dalam-ruu-ciptakerja (Accessed: 29 May 2020).

Riskiyono, J. (2015) 'Partisipasi Masyarakat Dalam Pembentukan Perundang-Undangan Untuk Mewujudkan Kesejahteraan', Aspirasi, 6(2), pp. 159-176.

Rongiyati, S. (2019) 'Menata Regulasi Pemberdayaan UMKM Melalui Omnibus Law', Info Singkat, Vol. XI(23), p. 1.

Sari, H. P. (2020) Gaduh Pasal 170 dalam Omnibus Law RUU Cipta Kerja, Benarkah Salah Ketik?, Kompas.com. Available at: https://nasional.kompas.com/read/2020/02/19/10480221/gaduh-pasal170-dalam-omnibus-law-ruu-cipta-kerja-benarkah-salah-ketik?page=all (Accessed: 30 May 2020).

Sasmita, R. A. (2012) Teori Hukum Integratif. Yogyakarta: Genta Publishing.

Simorangkir, E. (2016) Cetak Rekor, RI Jadi Negara Hukum Dengan Aturan Paling Banyak di Dunia, Detik.com. Available at: https://m.detik.com/finance/berita-ekonomi-bisnis/d-3344758/cetak-rekorri-jadi-negara-dengan-aturan-paling-banyak-di-dunia.

Soemitro, R. H. (1988) Metodologi Penelitian Hukum dan Jurimetri. Jakarta: Ghalia Indonesia.

Sugianto, D. (2020) Ini yang Bikin Buruh Ngotot Tolak RUU Cipta Kerja, Detik.com. Available at: https://finance.detik.com/berita-ekonomi-bisnis/d-4987950/ini-yang-bikin-buruh-ngotot-tolak-ruucipta-kerja (Accessed: 29 May 2020).

Supriadi (2005) Hukum Lingkungan di Indonesia. Jakarta: Sinar Grafika.

Suriadinata, V. (2019) 'Penyusunan Undang-Undang Di Bidang Investasi: Kajian Pembentukan Omnibus Law Di Indonesia', Refleksi Hukum: Jurnal Ilmu Hukum, 4(1), pp. 115-132. doi: 10.24246/jrh.2019.v4.i1.p115-132.

Tim detikcom (2020) ICEL Keberatan Izin Lingkungan Dihapus di Omnibus Law, Detik.com. Available at: https://news.detik.com/berita/d-4903995/icel-keberatan-izin-lingkungan-dihapus-diomnibus-law (Accessed: 29 May 2020).

Utantoro, A. (2020) Ahli Hukum UII Nilai RUU Cipta Kerja Banyak Permasalahan, Media Indonesia. Available at: https://mediaindonesia.com/read/detail/296236-ahli-hukum-uii-nilai-ruu-cipta-kerjabanyak-permasalahan.

Widnjoesoebroto, S. (2002) Hukum, Paradigma, Metode, dan Dinamika Masalahnya. Jakarta: ELSAM-HUMA.

Wijayanti, W. et al. (2013) 'Eksistensi Undang-Undang Sebagai Produk Hukum dalam Pemenuhan Keadilan Bagi Rakyat ( Analisis Putusan Mahkamah Konstitusi', Jurnal Konstitusi, 10(1), p. 182.

Yusa, I. G. and Hermanto, B. (2018) 'Implementasi Green Constitution di Indonesia: Jaminan Hak Konstitusional Pembangunan Lingkungan Hidup Berkelanjutan', Jurnal Konstitusi, 15(2), p. 313. 